\title{
HET RIJZEN DER OOSTKUST VAN JAVA,
}

DOOR

E M I L S T ÖH R.

Junghuhn heeft in zijn groot werk over Java (Java, zijne gedaante, zijn plantentooi en inwendige bouw) gewezen op de waarschijnlijkheid van het rijzen van den Zuid-westhoek van dat eiland in een betrekkelijk later tijdvak, omdat daar koraalbanken 7 tot 10 el boven de tegenwoordige gemiddelde oppervlakte der zee voorkomen. In 1858 heb ik eenige maanden op het schoone Java doorgebragt, vooral in het oostelijke gedeelte, waar ik de vulkanen beklom en bestudeerde, onder anderen den 3050 el hoogen Idjen, die niet ver van de oostkust gelegen is. Op weinige uren afstands van dezeu vulkaan, bij Batoe-dodol, bevindt zich eene uit bazaltische lava bestaande klip, die door de zee wordt bespoeld en waarover de postweg loopt. Van de kust naar het binnenland is deze lava door een vulkanisch gesteente van lateren tijd bedekt en alleen aan het strand komt de oudere lava geheel voor het oog ontbloot voor. Dit gesteente bestaat uit een van den Idjen afkomstigen lavastroom, een van de oudste, onderste stroomen, die in vroegeren tijd uit den berg zijn gevloeid en bijgedragen hebben, om zijn oorspronkelijk geraamte op te bouwen. Tegenwoordig werpt de Idjen slechts zand en asch uit, en bij groote uitbarstingen, zoo als die van 1817, verspreidt hij verwoestende modderstroomen, veroorzaakt, zoo door het uitwerpen van het kratermeer, als door tropische regenbuien; maar werkelijke lavastroomen zijn, voor zoover de geschiedenis reikt, hier niet meer voorgekomen. Bij Batoe-dodol breekt de hooger gemelde lavastroom plotseling af en vormt eenen 12 tot 15 el hoogen wand, zoodat het de schijn heeft, alsof de stroom in de zee vloeijende, daar afkoelende en zich opstuwende, dezen wand had opgerigt. Onder aan den wand, aan de zee, vindt men van bazaltsteen omgeven eene tegen de branding beschutte 
kom, een ongemeen lieflijke, stille badplaats, bovenal aanlokkelijk door het daarover hangende struikgewas. Zeer merkwaardig is daar eene bron van zoet, koel water, die uit de gekloofde bazalt voor den dag komt. Voor den Javaan, met zijn voor alles, wat de natuur oplevert, open gemoed, is dit stille plekje met zijne bron eene heilige plaats, waar hij zijne offeranden brengt. Toen ik dat oord bezocht, lagen er dan ook offerbloemen en vruchten en zelfs eenige koperen munt. Die van deze heilige plaats iets zou willen vernielen of verontreinigen, zou zeker door setang (duivel) dadelijk daarvoor worden gestraft, want de plaats heeft zulk een roep van heiligheid, dat men zelfs op verren afstand heilig water komt halen.

Maar laat ons terugkeeren tot het beschouwen van de bazaltklip. Zij bestaat uit eene vaste, digte, koolzwarte bazaltmassa, hier en daar met olivien gemengd en met eene platschelpachtige breuk. Hoogerop gaat zij in meer sponsachtig gesteente over. Duidelijk zijn hier concentrische schillen op te merken en de geheele wand is waaijersgewijze in stralen gekloofd. Hierdoor is de geheele massa in teerlingvormige stukken gespleten, die echter op sommige plaatsen naauwelijks eenige teerlingduimen groot zijn, maar waardoor het geheele gesteente uit scherphoekige basaltteerlingen schijnt te bestaan. Junghuhn kent ook de basaltrots, maar heeft de omgeving niet verder onderzocht, waardoor hem de kalksteen onbekend is, die hier later zal besproken worden. Junghuhn noemt in zijn werk de plaats Batoe-toetoel d. i. gestippelde of gevlekte steen, hoewel de kleur van het gesteente geheel gelijkvormig zwart is. De eigenlijke naam er van is Batoe-dodol, van batoe steen, dodol, eene zoete, donkerzwarte geleiachtige stof, die, in dobbelsteenen gesneden, op de markten als suikergoed wordt verkocht, en aan deze geleiachtige dobbelsteenen heeft de gekloofde bazalt den javaan herinnerd; - ten minste mij werd op de plaats zelf het woord dodol zoo uitgelegd.

Zoo ver als de zee met haren golfslag het gekloofde gesteente bespoelt, heeft zich in de scheuren en kloven, kalk afgezet en hetzelfde is ook het geval op andere plaatsen, waar de rots 13 tot 16 el hoog is en die de zee zelfs bij de sterkste stormen niet meer bereiken kan. Dikwijls vindt men daar eene ware breccie of puimsteen, doordien scherphoekige báaltstukken met een kalkcement zijn verbonden, terwijl ook de daar in zee vallende beek zulke stukken van hoogerop gelegen plaatsen mede- 
voert. Niet alleen in de scheuren en kloven heeft zich hier en daar kalk afgezet, maar eene kalklaag, 6 tot 9 el dik, is daar aanwerig, die deels tegen den lavastroom aanligt en hem deels bedekt. De kalksteén komt hier zoo menigvuldig voor, dat er in geen geringe hoeveelheid kalk gegraven en in een oven tot metselkalk gebrand wordt. De kalksteen is broos, geelachtig wit van kleur, vervuld met madreporen en astraceen en eenige niet te bestemmen schelpen. Hij bevat vele holen, die aan talrijke vleermuizen tot verblijfplaats verstrekken. Het is niet twijfelachtig, dat wij hier met een oud koraalrif te doen hebben; en, voor zoo ver met behulp van de medegebragte monsters konde bepaald worden, schijnen de koralen niet te verschillen van die, welke aldaar nog tegenwoordig in de zee leven. Het kalkrif zelf is nergens door bazalt of eenig ander vulkanisch gesteente doorbroken of daarmede bedekt, maar het ligt overal regelmatig op den lavastroom, eene vaste niet verbrokkelde massa vormende. Zelfs zijn veel vulkanische gesteenten van jongeren oorsprong dan de lavastroom hier en daar door de kalk tot eenen puim- of grindsteen verbonden. Het is niet twijfelachtig, dat de kalk de jongere en de lavastroom de oudere vorming is, en dat zich op den lavastroom, die vroeger in zee is gestroomd, later een koraalrif heeft gevormd, dat daarmede omtrent 15 el werd opgeheven. Hier is dus op Oost-Java zonder twijfel een rijzen van den bodem in een betrekkelijk nieuw tijdvak aanwezig, een tot dusver niet bekend voorbeeld.

Junghuhn heeft een dergelijk verschijnsel van den Zuid-westhoek van Java waargenomen en terwijl nu het oprijzen van den Noord-oosthoek insgelijks te bewijzen is, zoo is het niet onwaarschijnlijk, dat geheel Java aan zulk een oprijzen is onderhevig geweest, hetgeen bij een land, zoo rijk aan vulkanen, niet kan bevreemden. Hiervoor pleiten echter ook nog andere omstandigheden. De zeeëngte tusschen Java en Madura vèrzandt dagelijks meer en zal over eenige tientallen van jaren voor groote schepen niet meer bevaarbaar zijn. Het fort Erfprins, vroeger door de Nederlanders midden in de zeeëngte aangelegd, is heden reeds zoodanig door ondiepten omgeven, dat schepen daar niet meer kunnen aanleggen. Soerabaija, de groote hoofdstad in het oosten van Java, ligt niet ver van de zee aan de monding der Kali-Mas (de gouden rivier), die een arm is van de Kali-Brantas. Tusschen twee armen van den stroom heeft zich de vruchtbare delta van de Kali-Mas gevormd, die wegens zijne 
vruchtbaarheid de gouden streek (Betuwe) genoemd was. Die delta is meer dan twaalf vierkante geographische mijlen groot en eene vorming van den jongsten tijd, want de stad Modjopahit, de hoofdstad van het vroegere rijk van gelijken naam, ligt heden met hare bouwvallen acht uren gaans van de zee verwijderd en naar Zollingers waarneming 31 el boven de oppervlakte der zee. Volgens javaansche overleveringen was zij nog in de $13^{\mathrm{e}}$ eeuw aan het zeestrand gelegen; terwijl in 1250 van daar vloten uitliepen, die Singapore moesten veroveren.

De uitbarstingen der nog werkende vulkanen leveren wel is waar zulke ontzettend groote hoeveelheden zand, asch en modder op, die door beken en stroomen naar de vlakte gebragtworden, dat zij eene hoogst aanzienlijke menigte bouwstoffen voor de vorming van een delta aanbrengen. Zoo wordt immers de hoeveelheid zand en asch, die bij de laatste groote uitbarsting van den Kloet in Maart 1864 is gevallen, op vele millioenen vierkante ellen geschat; maar dit verschijnsel schijnt evenwel niet voldoende, om het ontstaan te verklaren van eene zoo uitgestrekte delta in den betrekkelijk korten tijd van zes honderd jaren, te minder omdat de door den Kali-Brantas en zijne takken omspoelde vulkanen, met uitzondering alleen van den Kloet, reeds lang zijn uitgedoofd, zoo als de Wilis, Kawie, Broeboe, Penanggoengan of, zoo als de Ardjoeno, reeds onder de uitgedoofde vulkanen worden geteld, terwijl ook deze voor zoo ver de geschiedenis reikt, geen uitbarsting meer gehad heeft, hoewel er zich nog solfataren op zijn top bevinden. De twee andere naastbịj liggende vulkanen Tengger en Smeroe kunnen bij de vorming van de delta naauwelijks in aanmerking komen, omdat zij alleen van de oostzijde door de hoogst gelegen takken van den KaliBrantas worden bespoeld. Ook de ligging van Modjopahit, 31 el boven de zee, mag niet geheel over het hoofd worden gezien, omdat bij de over het algemeen lage ligging der kusten deze stad vroeger, toen zij nőg aan zee lag, bezwaarlijk 31 el boven hare oppervlakte verheven geweest kan zijn. Het is daarom waarschijnlijker, dat de vorming van de delta en de toenemende verzanding van straat Madura aan twee oorzaken moet toegeschreven worden: aan het afvoeren door rivieren en beken van stoflè, die aan de bergen ontleend zijn en tevens aan eene nog voortdurende rijzing van het land.

Ten slotte nog eene opmerking betreffende de steensoorten der vulkanen van Oost-Java. De meeste steensoorten van oudere 
dagteekening, de eigenlijke lava's van vroegeren tijd, zijn bazaltische lava's of trachyt-dolerieten. Gewone trachyt is, met eene enkele vitzondering op den Ardjoeno, door mij nergens opgemerkt en ook dit punt vereischt nog nader onderzoek. In alle andere steensoorten heb ik slechts triclinische veldspaat opgemerkt, maar geen sanidin. Dit strijdt met de opgave van Junghuhn, die trachyt als het heerschende gesteente beschouwt. Deze door mij bij de vulkanen van Oost-Java gemaakte opmerkingen zijn door Prölss ook voor Midden-Java bevestigd, terwijl naar zijne onlangs in Leonard's jaarboek (1864 afl. IV) medegedeelde scheikundige ontledingen ook de daar voorkomende lava's tot de bazaltische of trachyt-doleriet lava's blijken te behooren, maar niet tot de trachytische. Boven op deze oudere lava's ligt de jongere vulkanische vorming, zand, asch, lapillen en modder; want geen vulkaan van Oost-Java en zelfs van het geheele eiland braakt tegenwoordig nog vloeibare lava uit, maar alleen losse steensoorten. 